\title{
VARIASI GENETIK MASYARAKAT SOROH PANDE DI KABUPATEN GIANYAR BERDASARKAN TIGA LOKUS DNA MIKROSATELIT AUTOSOM
}

\author{
GENETIC VARIATION OF PANDE CLAN IN GIANYAR REGENCY \\ BASED ON THREE AUTOSOMAL MICROSATELLITES DNA LOCI
}

\author{
Gusti Ayu Putri Arnila, I Ketut Junitha dan Made Pharmawati \\ Prodi Biologi, F. MIPA, Universitas Udayana \\ Email : putri24195@gmail.com
}

\section{INTISARI}

Perkembangan ilmu forensik berkaitan erat dengan penggunaan analisa DNA mikrosatelit sebagai salah satu sarana yang paling akurat untuk mengungkap identitas seseorang. Penelitian ini dilaksanakan untuk mengetahui ragam alel yang tersebar pada masyarakat soroh Pande di Kabupaten Gianyar dengan menggunakan tiga lokus DNA mikrosatelit autosom yaitu D2S1338, D13S317 dan D16S539. Berdasarkan hasil analisa ditemukan 23 ragam alel dengan rata-rata 7,3 per lokus. Rata-rata nilai heterozigositas dari tiga lokus yang digunakan adalah 0,817 \pm 0,029 menunjukkan bahwa secara genetik masyarakat soroh Pande sangat bervariasi. Rata-rata nilai Power of Discrimination adalah 0,893. Tingginya nilai Power of Discrimination menunjukkan bahwa ketiga lokus ini baik digunakan untuk membedakan antar individu pada kepentingan forensik.

Kata kunci: Soroh Pande, DNA Mikrosatelit, Heterozigositas, Power of Discrimination

\begin{abstract}
The development of forensic science is closely related to the use of microsatellite DNA analysis as one of the most accurate means to reveal the person's identity. This study was conducted to determine the range of alleles distribution in society of soroh Pande in Gianyar. Three autosomal microsatellite DNA loci were used which were D2S1338, D13S317 and D16S539. Based on the analysis there were 23 varieties of allele found with an average of 7.3 allele per locus. The average level of heterozygosity from three loci used was $0.817 \pm 0.029$ indicates that soroh Pande genetically very varied community. The average value of the Power of Discrimination was 0.893. The high value of the Power of Discrimination showed that the three loci were best used to distinguish between individuals in forensic studies.
\end{abstract}

Keywords: Soroh Pande, Microsatellite DNA, Heterozygosity, Power of Discrimination

\section{PENDAHULUAN}

Meningkatnya kasus kejahatan dan banyaknya bencana alam di Indonesia mengakibatkan banyak korban yang tewas dan sulit dikenali secara fisik, sehingga meningkatkan jumlah korban yang tidak diketahui identitasnya. Perkembangan ilmu forensik berkaitan erat dengan penggunaan analisa DNA mikrosatelit sebagai salah satu sarana yang paling akurat untuk mengungkap identitas korban (Octavia, 2015; Junitha dan Alit, 2011).

Keberadaan masyarakat Hindu di Bali membentuk kelompok berdasarkan profesi dan garis keturunan lakilaki (patrilineal) yang disebut sebagai soroh (klan). Salah satu diantara soroh-soroh tersebut adalah soroh Pande yang tersebar di Pulau Bali. Soroh Pande meyakini kelompoknya merupakan keturunan dari leluhur yang memiliki profesi "memande" (Darmada dkk., 2007).
Berdasarkan sejarah, masuknya masyarakat soroh Pande yang berasal dari berbagai sumber genetik sejak zaman pra sejarah dan menjadi cikal bakal soroh Pande saat ini terjadi dalam beberapa gelombang. Penyebaran dan perubahan tempat tinggal masyarakat soroh Pande dipengaruhi oleh kedatangan yang terjadi secara bertahap serta situasi dan kondisi pada zaman kerajaan, hingga sampailah masyarakat soroh Pande di Kabupaten Gianyar (Darmada dkk., 2007).

Penanda DNA mikrosatelit dikenal juga sebagai Simple Sequence Repeat (SSR). Pada bidang genetika, khususnya kedokteran forensik, DNA mikrosatelit juga disebut sebagai Short Tandem Repeat (STR) memiliki tingkat akurasi yang tinggi, sangat tepat digunakan untuk kepentingan mengungkap identitas korban (Junitha dan Alit, 2010; Butler, 2004). Penanda DNA mikrosatelit terdiri dari 2-6 pasang basa yang berulang dengan 


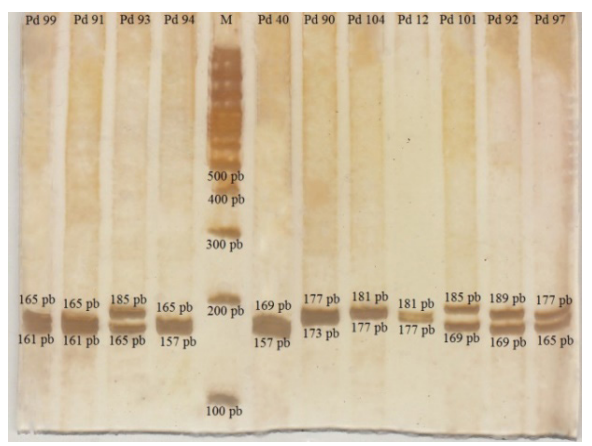

A

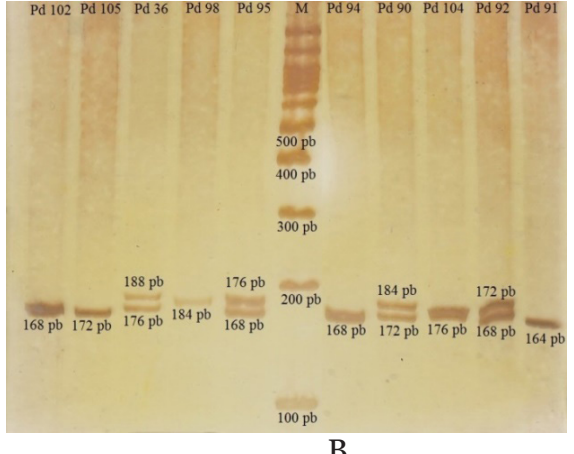

B

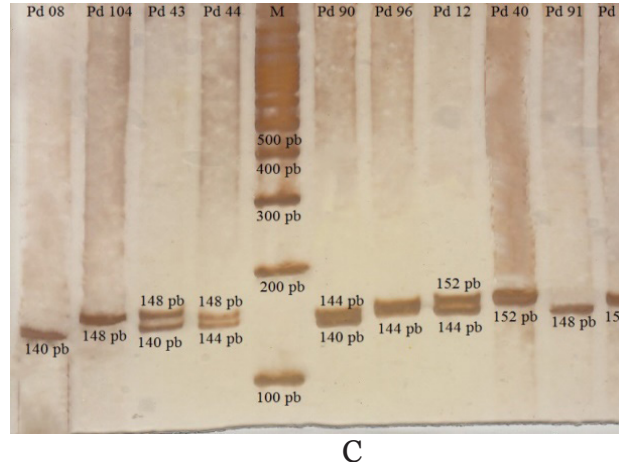

Gambar 1 (A) Lokus D2S1338, (B) Lokus D13S317, (C) Lokus D16S539(M) Lajur marker standar 100 bpladder, (angka) panjang alel dalam $\mathrm{pb}$

kecepatan mutasi relatif tinggi yaitu 0-8 x 10-3(Weber and Wong, 1993). Maka dari itu DNA mikrosatelit sering digunakan untuk mempelajari kekerabatan antar populasi di Indonesia (Maharani dkk., 2014).

Luas wilayah pulau Bali dari tahun 2010 hingga saat ini sekitar 5.636,66 km² dengan kepadatan penduduk yaitu 690 per $\mathrm{km}^{2}$ dengan total jumlah penduduk sebesar 3.890.756 jiwa. Dari seluruh penduduk Bali tersebut sebesar 643.473 jiwa merupakan penduduk pendatang yang tinggal baik di kota-kota maupun di pedesaan (Badan Pusat Statistik, 2010). Masyarakat di Bali dewasa ini sudah terbedakan menjadi beberapa kelompok, baik berdasarkan perbedaan agama maupun perbedaan leluhur atau kawitan yang disebut soroh. Dengan demikian penelitian variasi genetik untuk pembuatan database DNA kelompok-kelompok masyarakat di Bali akan lebih baik bila menggunakan pendekatan soroh dibandingkan dengan pendekatan wilayah. Semua soroh yang ada sudah menyebar di seluruh Bali bahkan sampai ke luar Bali demikian juga halnya dengan soroh Pande. Perkembangan masyarakat soroh Pande sudah berlangsung sejak mulai berdirinya Kerajaan Gianyar yang mendatangkan warga Pande dari luar Gianyar seperti dari Taman Bali. Dalam perkembangan selanjutnya wilayah Gianyar juga kedatangan warga Pande dari berbagai daerah dan kawitan yang menempati hampir seluruh desa di Gianyar yang belum ada warga Pandenya di desa tersebut (Darmada dkk., 2007).

Berdasarkan latar belakang tersebut, maka dilakukanlah penelitian menggunakan tiga lokus DNA mikrosatelit autosom untuk mengetahui ragam alel yang tersebar pada masyarakat soroh Pande di Kabupaten Gianyar serta sebagai referensi untuk memudahkan pengungkapan identitas korban yang tidak dapat dikenali secara fisik dan bermanfaat dalam kepentingan forensik.

\section{MATERI DAN METODE}

Pengambilan sampel menggunakan metode non infasive sampling yaitu mengambil sampel sel epitel mukosa mulut tanpa menyakiti probandus (Laksmita dkk., 2015; Junitha dan Octavia, 2015;Wulandari, 2014). Sampel diambil dari 30 laki-laki soroh Pande di Kabupaten Gianyar yaitu 3-5 sampel yang mewakili masing-masing kecamatan tergantung dari keberadaan Pura Dadia pada bulan November 2015. Sampel sel epitel mukosa mulut diambil dengan cara mengusapkan cotton bud steril di bagian dalam pipi probandus kemudian dimasukkan dalam tabung $1,5 \mathrm{~mL}$ yang berisi $500 \mu \mathrm{L}$ buffer lysisDPZ (10mM NaCl + 100mM EDTA + 100mM Tris-Cl + Urea 4M + aquades). Ekstraksi DNA dilakukan dengan metode fenol-kloroform (Jehuda, 2011; Junitha dan Sudirga, 2007; Sambrook and Russel, 2001). Sampel hasil ekstraksi diamplifikasi dengan tiga lokus DNA mikrosatelit autosom yaitu D2S1338, D13S317 dan D16S539 pada mesin PCR SenscQuestLabcycler (Junitha dkk., 2009; Handoyo dan Rudiretra, 2000). Amplikon dielektroforesis dengan gel poliakrilamide (PAGE) 10\% dan divisualisasi dengan pewarnaan perak nitrat (Laksmita dkk., 2015; Junitha dan Octavia, 2015; Tegelström, 1986). Penentuan ukuran DNA sebagai alel dalam satuan panjang basa (pb) dengan memplot jarak migrasi amplikon pada kertas semilog (Hutchinson, 2001).Frekuensi dan Keragaman genetik dihitung dengan rumus Nei (1987) dan Power of Discrimination dihitung dengan rumus Butler (2005).

\section{HASIL}

Pada lokus D2S1338 diperoleh hasil amplifikasi sebanyak 29 sampel dengan sembilan ragam alel. Pada lokus ini alel $189 \mathrm{pb}$ merupakan alel terpanjang dan alel terpendek adalah $157 \mathrm{pb}$. Pada lokus D13S317 sebanyak 28 sampel berhasil teramplifikasi dan menghasilkan tujuh alel (164-188pb). Primer D16S539 berhasil mengamplifikasi 29 sampel dan menghasilkan tujuh ragam alel (140-164 pb). Hasil visualisasi, jumlah ragam alel dan frekuensi pada masing-masing lokus disajikan pada Gambar 1 dan Tabel 1. Gambar 1. Hasil visualisasi pada PAGE 10\%

\section{PEMBAHASAN}

Penelitian ini menggunakan sampel DNA dari sel epitel mukosa mulut masyarakat soroh Pande diambil dari 30 orang probandus yang secara turun temurun tinggal di 
Tabel 1. Ragam dan Frekuensi Alel Masyarakat soroh Pande di Kabupaten Gianyar

\begin{tabular}{cccccc}
\hline \multicolumn{2}{c}{ Lokus D2S1338 } & \multicolumn{2}{c}{ Lokus D13S317 } & \multicolumn{2}{c}{ Lokus D16S539 } \\
Alel (pb) & $\begin{array}{c}\text { Fre- } \\
\text { kuensi }\end{array}$ & Alel (pb) & $\begin{array}{c}\text { Fre- } \\
\text { kuensi }\end{array}$ & Alel (pb) & $\begin{array}{c}\text { Fre- } \\
\text { kuensi }\end{array}$ \\
\hline 157 & 0,07 & 164 & 0,16 & 140 & 0,07 \\
161 & 0,05 & 168 & 0,41 & 144 & 0,26 \\
165 & 0,21 & 172 & 0,16 & 148 & 0,34 \\
169 & 0,16 & 176 & 0,11 & 152 & 0,16 \\
173 & 0,07 & 180 & 0,02 & 156 & 0,10 \\
177 & 0,16 & 184 & 0,11 & 160 & 0,02 \\
181 & 0,19 & 188 & 0,04 & 164 & 0,05 \\
185 & 0,09 & & & & \\
189 & 0,02 & & & & \\
\hline
\end{tabular}

Keterangan :

$\mathrm{pb}=$ Satuan panjang basa

Tabel 2. Nilai Heterozigositas dan Power of Discrimination

\begin{tabular}{ccc}
\hline Lokus & Heterozigositas & $\begin{array}{c}\text { Power of } \\
\text { Discrimination }\end{array}$ \\
\hline D2S1338 & $0,868 \pm 0,042$ & 0,952 \\
D13S317 & $0,766 \pm 0,017$ & 0,847 \\
D16S539 & $0,785 \pm 0,022$ & 0,876 \\
Rata-rata & $0,817 \pm 0,029$ & 0,893 \\
\hline
\end{tabular}

Kabupaten Gianyar. Sampel diambil pada masing-masing kecamatan di Kabupaten Gianyar dan disesuaikan dengan keberadaan Pura Dadia Pande di wilayah tersebut. Sebanyak tujuh probandus berasal dari empat Pura Dadia di Kecamatan Gianyar. Lima probandus dari lima Pura Dadia di Kecamatan Blahbatuh, empat probandus dari tiga Pura Dadia di Kecamatan Tampaksiring. Tiga probandus dari tiga Pura Dadia di Kecamatan Sukawati, enam probandus dari lima Pura Dadia di Kecamatan Ubud, dan sebanyak tiga probandus berasal dari tiga Pura Dadia di Kecamatan Tegallalang serta dua berasal dari dua Pura Dadia di Kecamatan Payangan.

Masyarakat soroh Pande terdiri dari beberapa kelompok berdasarkan keahliannya. Masyarakat soroh Pande yang masih memiliki bukti sejarah seperti kelompok Pande Tusan, Pande Tatasan, Pande Sesana, Pande Tonja, Pande Taman Bali, Pande Bungbungan, Pande Mas, Pande Bangke Maong dan Pande Dalem Gandamayu akan menyatakan dirinya berasal dari keturunan kelompok Pande tersebut. Adapula masyarakat soroh Pande lainnya yang menyatakan bahwa dirinya termasuk kelompok Pande Besi, karena mereka kehilangan bukti sejarah leluhurnya atau bahkan menganggap semua kelompok Pande itu sama. Hal ini dipertegas dengan dibentuknya organisasi Maha Semaya Warga Pande (MSWP) yang menyatakan bahwa semua warga Pande berasal dari satu leluhur yang sama yaitu dari Mpu Brahma Wisesa agar bersatu tanpa memandang siapa yang paling tinggi dan tidak saling merendahkan (Jiwa, 2013).

Lokus D2S1338 menunjukkan banyakya ragam alel tertinggi yaitu sebanyak sembilan alel yang berkisar dari (189-157 pb) dengan frekuensi alel tertinggi adalah alel $165 \mathrm{pb}(0,21)$ dan frekuensi alel terendah adalah alel $189 \mathrm{pb}(0,02)$ (Tabel 1). Pada penelitian populasi masyarakat di Brescia (Itali) dengan menggunakan lokus D2S1338 menghasilkan 12 ragam alel (Cerri et al. 2004). Ragam alel tertinggi hasil penelitian Octavia (2015) pada masyarakat Dayak Kaharingan di Kota Palangkaraya juga ditemukan pada lokus D2S1338 yaitu sebanyak 11 alel dengan ukuran alel berkisar antara (205-157 pb). Sedangkan pada penelitian Junitha dan Alit (2011) alel masyarakat Bali Mula di Desa Sembiran Buleleng berkisar antara (197-165 pb). Alel yang dihasilkan lokus D2S1338 pada masyarakat soroh Pande di Kabupaten Gianyar berada di antara alel-alel yang dihasilkan pada penelitian suku bangsa Dayak, yang menunjukkan bahwa alel-alel ini secara umum masih tergolong ke dalam sukusuku yang ada di Indonesia dan secara khusus termasuk pada alel yang dimiliki oleh masyarakat Bali seperti yang dihasilkan pada penelitian Junitha dan Alit (2011).

Suku bangsa Batak dan Dayak merupakan masyarakat yang termasuk dalam kelompok Protomelayu yang datang ke Kepulauan Indonesia lebih awal dibandingkan masyarakat Bali dan Jawa yang termasuk kedalam kelompok Deutromelayu (Belwood, 2000). Variasi genetik akan meningkat seiring perjalanan waktu dan berkembangnya suatu populasi karena proses mutasi yang terjadi.

Pada lokus D13S317 dihasilkan sebanyak tujuh alel antara (188-164 pb) dengan frekuensi tertinggi pada alel $168 \mathrm{pb}(0,41)$ dan frekuensi terendah pada alel $180 \mathrm{pb}$ $(0,02)$. Penelitian mengenai populasi di Marmara, Turki memperoleh tujuh ragam alel pada lokus D13S317 (Çakir, 2002). Penelitian Unadi dkke (2010) yaitu alel pada suku Batak yang tinggal di Kota Denpasar dan Kabupaten Badung menghasilkan alel yang berkisar antara (204-168 pb) pada lokus D13S317. Penelitian variasi genetik suku Dayak di Kota Palangkaraya oleh Junitha dan Octavia (2015) pada lokus ini ditemukan alel yang berkisar antara (200-16o pb). Penelitian Forensik Internasional yang dilaksanakan oleh Butler (2006) menunjukkan bahwa lokus D13S317 menghasilkan alel yang berkisar antara (273-193 pb).

Frekuensi alel tertinggi pada lokus D13S317 adalah alel $168 \mathrm{pb}$ dengan frekuensi o,41 hal ini menunjukkan bahwa kabanyakan masyarakat soroh Pande memiliki alel $168 \mathrm{pb}$. Alel ini mungkin merupakan alel founding father dari masyarakat soroh Pande. Sedangkan alel lain dari lokus ini merupakan alel yang berkembang melalui mutasi bertahap satu unit (one step mutation) menjadi alel lainnya hingga menghasilkan alel dengan frekuensi terendah sebagai hasil mutasi tahap akhir (Dwitiari, 2012; Unadi dkk., 2010; Junitha dan Alit, 2010).

Hasil amplifikasi pada lokus D16S539 menunjukkan terdapat tujuh alel antara (164-140 pb) dengan frekuensi tertinggi yaitu pada alel $148 \mathrm{pb}(0,34)$ dan frekuensi alel terendah pada alel $160 \mathrm{pb}(0,02)$. Penelitian keragaman genetik dengan menggunakan 15 lokus pada populasi Moroccan diantaranya menggunakan lokus D16S539 juga memperoleh tujuh ragam alel (Reguig et al.2015). Penelitian pada lokus D16S539 yang dilaksanakan oleh 
Laksmita dkk., (2015) mengenai ragam alel pada tiga generasi masyarakat Bali menghasilkan alel yang berkisar antara (168-148 pb). Penelitian Octavia (2015) yaitu pada masyarakat Dayak Kaharingan di Kota Palangkaraya memperoleh ragam alel yang berkisar antara (164132 pb) pada lokus D16S539. Penelitian Butler (2006) mengenai Forensik Internasional memperoleh ragam alel berkisar dari (277-233 pb) pada lokus D16S539. Kisaran alel yang dihasilkan oleh sampel masyarakat soroh Pande pada lokus D16S539 masih mengarah pada kisaran alel yang dimiliki suku-suku yang ada di Indonesia maupun masyarakat Bali.

Berdasarkan data hasil perhitungan, nilai heterozigositas tertinggi terdapat pada lokus D2S1338(o,868 \pm 0,042), diikuti oleh lokus D16S539(0,785 \pm 0,022) dan lokus D13S317(0,766 \pm 0,017). Tingginya nilai heterozigositas pada lokus D2S1338 disebabkan karena banyaknya ragam alel yang didapat dibandingkan pada lokus lainnya yang masing-masing menghasilkan tujuh ragam alel. Nilai heterozigositas berkisar dari nol sampai satu, apabila heterozigositas menunjukkan angka mendekati nol maka nilai keragaman genetik pada suatu lokus tersebut rendah begitu pula sebaliknya, jika nilai heterozigositas mendekati angka satu maka keragaman genetik pada suatu lokus tersebut tinggi (Octavia, 2015; Nei, 1987). Berdasarkan hal tersebut rata-rata nilai heterozigositas dari tiga lokus tersebut adalah o,817 \pm 0,029 yang mendekati angka satu maka keragaman genetik pada Masyarakat soroh Pande cukup tinggi dan berarti bahwa secara genetik masyarakat soroh Pande sangat bervariasi.

Penelitian Junitha dan Alit (2011), tentang ragam alel pada masyarakat Bali Aga, Desa Sembiran, Kabupaten Buleleng didapatkan ragam alel yang lebih sedikit pada lokus D2S1338, D13S317 dan D16S539. Banyaknya ragam alel yang diperoleh pada masyarakat soroh Pande disebabkan karena sampel yang diambil adalah populasi masyarakat soroh Pande di seluruh Kabupaten Gianyar, sedangkan ragam alel masyarakat Bali Aga diambil dari satu desa sehingga meghasilkan ragam alel yang lebih sedikit.

Keragaman genetik masyarakat soroh Pande yang tinggi dapat disebabkan oleh banyaknya sumber genetik yang berasal dari berbagai tempat seperti Teluk Tonkin Cina, Dongson Vietnam dan Kerajaan Majapahit dari Jawa (Darmada dkk., 2007). Disamping itu, pola perkawinan masyarakat soroh Pande terbilang acak karena masyarakat tersebut tidak memiliki aturan perkawinan yang membatasi suatu perkawinan antar soroh seperti adat di Desa Tenganan Pegringsingan Karangasem (Junitha, 2004).

Nilai heterozigositas dan Power of Discrimination sangat dipengaruhi oleh ragam alel yang dihasilkan serta frekuensinya. Semakin banyak alel yang dihasilkan maka semakin tinggi nilai Heterozigositas dan Power of Discrimination yang dihasilkan, sehingga lokus tersebut baik digunakan dalam melakukan analisa DNA untuk keperluan forensik pada masyarakat soroh Pande di Kabupaten Gianyar (Junitha dan Octavia, 2015). Nilai heterozigositas berbanding lurus dengan nilai Power of Discrimination. Nilai Power of Discrimination tertinggi yaitu D2S1338 (o,952) diikuti lokus D16S539 (o,876) dan D13S317 (o,847). Power of Discrimination berperan dalam membedakan individu secara genetik atau antara dua individu yang tidak memiliki hubungan keluarga (Octavia, 2015; Malyarchuk et al. 2007). Nilai Power of Discrimination pada tiga lokus yang digunakan dalam penelitian ini menghasilkan nilai yang cukup tinggi, sehingga ketiga lokus ini akan memberikan peluang lebih tinggi untuk membedakan profil DNA antar individu dalam suatu populasi. Oleh karena itu, ketiga lokus ini baik digunakan dalam analisis DNA untuk menentukan identitas individu dalam forensik terutama pada masyarakat soroh Pande.

\section{SIMPULAN}

Pada masyarakat soroh Pande ditemukan 23 ragam alel. Rata-rata nilai heterozigositas dari tiga lokus yang digunakan adalah $0,817 \pm 0,029$ sedangkan rata-rata nilai Power of Discrimination adalah 0,893. Ketiga lokus (D2S1338, D13S317 dan D16S539) baik digunakan dalam analisa DNA untuk kepentingan forensik pada masyarakat soroh Pande.

\section{UCAPAN TERIMAKASIH}

Terimakasih kami sampaikan kepada seluruh masyarakat soroh Pande di Kabupaten Gianyar yang telah sukarela menjadi probandus dalam penelitian ini. Demikian juga kepala Laboratorium Serologi dan DNA Forensik UPT Forensik Universitas Udayana serta Laboratorium Pusat Studi Primata Universitas Udayana.

\section{KEPUSTAKAAN}

Badan Pusat Statistik. 2010. Luas Wilayah, Jumlah Rumah Tangga dan Jumlah Penduduk Hasil Sensus Penduduk 2010 Menurut Kabupaten/Kota di Bali, [Online], Available: "www.bali.bps. go.id" [1 April 2016].

Belwood, P. 200o. Prasejarah Kepulauan Indo-Malaysia. PT Gramedia Sarata Utama. Jakarta.

Butler, J.M. 2004. Short Tandem Repeat Analysis for Human Identity Testing. Curr. Protoc. Hum. Genet. 14:14-18.

. 2005. Forensic DNA Typing (2nd Edition). New York : Elsevier Academy Press.

. 2006. Genetics and Genomics of Core Short Tandem Repeat Loci Used in Human Identity Testing. J. Forensic Sci. 51(2):253-265.

Çakir, A. H., F. Simşek, A. Celebioğlu, and B. Taşdelen. 2002. Analysis of The Three STR Loci(D16S539, D7S820, D13S317) in a Population Sample of Marmara Region of Turkey. J. Cell Mol. Biol. 1:25-30.

Cerri, N., S. Manzoni, A. Verzeletti, and F. De Ferrari. 2004. Population Data on D16S539, D2S1338 and D19S433 Loci in a Population Sample From Brescia (Italy). International Congres Series $1261:$ 210-212. 
Darmada, N.W., M.G. Sutama dan J. Atmaja. 2007. Asal-usul Warga Pande di Bali : Dilengkapi dengan Dadia Warga Pande. Bali Media Adhikarsa. Bali.

Dwitiari, M. Ç. 2012. Variasi Genetik Masyarakat Bali Mula di Desa Sembiran Buleleng dengan Penanda DNA Mikrosatelit. J. Biol. XVI(1): 9-14.

Handoyo, D. dan A. Rudiretra. 200o. Prinsip Umum dan Pelaksanaan Polymerase Chain Reaction (PCR). J. Unitas 9(1):17-29.

Hutchinson F. 2001. DNA Band Size Semi-log Plotting. Cancer Research Center Science Education Partnership 06.26.01.

Jehuda, V. 2011.Ekstraksi DNA dari Sperma Pada Kondom dan Kain yang Tersimpan Sampai Dua Belas Hari. J. Simbiosis 1(1):28-39.

Jiwa, P.M.P. 2013.Prasasti \& Babad Pande. Penerbit PĀRAMITA. Surabaya.

Junitha, I.K. 2004. Keragaman Genetik Masyarakat di Desa-desa Bali Aga Berdasarkan Analisis DNA dan Sidik Jari. (Disertasi). Sekolah Pasca Sarjana Institut Pertanian Bogor. (Unpublish).

Junitha, I.K. dan I. B. Alit. 2010. Ragam Alela Tujuh Lokus Penanda Genetik DNA Mikrosatelit Masyarakat Bali Aga Desa Sembiran Kabupaten Buleleng Bali. Prosiding Seminar Nasional Biologi Fakultas Biologi UGM : 655-663.

.2011. Ragam Alel Mikrosatelit DNA Autosom Pada Masyarakat Bali Aga Desa Sembiran Kabupaten Buleleng Bali. Biota 16(1): 63-69.

Junitha, I.K. dan L.E. Octavia. 2015. Studi Pendahuluan Variasi Genetik Masyarakat Dayak di Kota Palangka Raya Kalimantan Tengah Berdasarkan Enam Lokus Mikrosatelit Autosom. Prosiding Seminar Nasional Biosains2 : 242-247.

Junitha, I.K. dan S.K. Sudirga. 2007. Variasi DNA Mikrosatelit Kromosom Y pada Masyarakat Bali Terunyan. Hayati J.Bioscience 14(2):59-64.

Junitha, I.K., S.K. Sudirga dan M.S. Wijana. 2009. Variasi Genetik DNA Mikrosatelit Kromosom-Y Soroh Pasek Kayu Selem di Bali. Berkala Penelitian Hayati. Edisi Khusus 3A:39-43.

Laksmita, A.S., I K. Junitha dan Ni L. Watiniasih. 2015. Struktur Genetik dan Ragam Alel Tiga Generasi Masyarakat Bali Ber- dasarkan Lima Lokus Penanda DNA Mikrosatelit Autosom. Metamorfosa 2(2):58-65.

Maharani, D., I.G. Soma dan I N. Wandia. 2014. Karakteristik Lokus Mikrosatelit D10S1432 pada Populasi Monyet Ekor Panjang di Taman Nasional Alas Purwo Banyuwangi. Indonesia Medicus Veterinus 3(3):244-251.

Malyarchuk, B.A., M. Woźniak, J. Czarny, M.V. Derenko, T. Grzybowski and D. Miścicka-Śliwka. 2007. Variation of 15 Autosomal Microsatellite DNA Loci in the Russian Population. Mol. Biol. 41(1):1-4.

Nei, M. 1987. Molecular Evolutionary Genetics. Columbia University Press. New York.

Octavia, E.L. 2015. Identifikasi Alel Pada Tiga Lokus DNA Mikrosatelit Autosom Masyarakat Dayak Kaharingan di Kota Palangka Raya. (Skripsi). Jurusan Biologi. Fakultas Matematika dan Ilmu Pengetahuan Alam. Universitas Udayana. Bali.

Reguig, A., B.E. Houate, H.Yahia, Y. Naasse, H. Rouba, N. Harich. 2015. Genetic Diversity of 15 Autosomal STR Loci in a Moroccan Population. Intl. J. Sci. Res. Publ. 5(11):323-326.

Sambrook, J. and D.W. Russel. 2001. Molecular Cloning A Laboratory Manual 3rd Edition. Cold Spring Harbor Laboratory Press. New York.

Tegelström, H. 1986. Mitochondrial DNA in Natural Population : an Improved Routine for Screening of Genetic Variation Based on Sensitive Silver Staining. Electrophoresis 7: 226-229.

Unadi, Y.C., I. Narayani dan I.K. Junitha. 2010. Variasi Genetik Suku Batak yang Tinggal di kota Denpasar dan Kabupaten Badung Berdasarkan Tiga Lokus Mikrosatelit DNA Autosom. J. Biol. XIV(1):33-38.

Weber, J. dan C. Wong. 1993. Mutation of Human Short Tandem Repeats. Human Molecular Genet. 2(8):1123-1128.

Wulandari, N.P.P., I.K. Junitha dan N. Wirasiti. 2014. Penelitian Pendahuluan Variasi Genetik Masyarakat Soroh Pande Berdasarkan Penanda DNA Mikrosatelit Kromosom Y : Masyarakat Soroh Pande Desa Abiansemal, Badung. J.Biol. XVIII (1):5-9. 